Eixo temático: Mediação Teatral e Metodologias de Ensino

\title{
O Jogo teatral como metodologia transdisciplinar: discutindo arte e sustentabilidade
}

The theatrical game as a transdisciplinary methodology: discussing art and sustainability

El juego teatral como metodología transdisciplinaria: discutiendo arte y sostenibilidad

RESUMO: O presente trabalho apresenta uma proposta de metodologia de ensino transdisciplinar, que visa valer-se do jogo teatral como articulador de conhecimentos e saberes transdisciplinares. Pesquisa esta que está sendo desenvolvida no Programa Interdepartamental de Pós-graduação em Artes, Urbanidades e Sustentabilidade, PIPAUS, pela Universidade Federal de São João del-Rei, UFSJ. Tem-se como eixo principal para a discussão, os conhecimentos teatrais e a sustentabilidade tendo em vista a possibilidade de, a partir do jogo teatral, conseguir ampliar o debate e o conhecimento relativos à sustentabilidade, ao possibilitar ao aluno/jogador vivenciá-los de maneira dinâmica e concisa, e, dessa maneira, permitir aos mesmos a possibilidade de aprender vários conhecimento distintos vinculados às questões climática e sustentável em um só jogo.

PALAVRAS-CHAVE: Jogo teatral. Transdisciplinaridade. Sustentabilidade.

ABSTRACT: The present work allocates the hypothesis of a proposal of a transdisciplinary teaching methodology, which aims to use the theatrical game as an articulator of transdisciplinary knowledge. It has as main axis for the discussion the theatrical knowledge and the sustainability in view of the possibility of, from a theatrical game, to be able to cover knowledge of the subjects mentioned, that can lead the student / player to experience them in a dynamic and concise way, where they can learn several distinct knowledge from a single game.

KEYWORDS: Theatrical game. Transdisciplinarity .Sustainability 


\section{1- INTRODUÇÃO}

Segundo Ubiratan D’Ambrosio (2012) a referência que ele faz à maneira de ensino versa sobre o conteúdo do currículo escolar utilizado nas escolas no Brasil, que se resume apenas na explicação do professor e a avaliação e ao final deste processo de ensino. Neste processo os alunos que não conseguem alcançar os pontos necessários nas avaliações são reprovados o que gera a repetência em série e a desmotivação do aluno.

Esta situação visou à busca de uma possibilidade de desenvolver uma pesquisa que criasse uma metodologia de ação educativa utilizando o jogo teatral como articulador de saberes transdisciplinares tendo como mote o resgate da dimensão lúdica no adolescente, através do jogo. Desta maneira possibilitar-se-ia ao aluno aproximar sua realidade aos conteúdos trabalhados na escola e a hipótese para isso é que o jogo pode aproximar a realidade do aluno e os saberes escolares de forma dialógica, despertando o interesse do aluno pelos assuntos abordados em sala.

\section{2- CONJETURAS:}

\subsection{Jogo Teatral}

Johan Huizinga em seu livro Homo Ludens discorre sobre o jogo e como ele é um elemento da cultura humana, observa como os elementos lúdicos estão presentes na política, na guerra, no amor, na poesia e em tantas outros aspectos do humano. Roger Caillois, em Os jogos e os homens, discorre sobre as regras do jogo e sobre o jogo ser livre: “Todo jogo é um sistema de regras. Estas definem o que é ou não jogo, o que é permitido e proibido” (p. 11). E destaca que o jogo acontece quando quisermos e pelo tempo que quisermos, enfatizando a ação livre do jogo.

Toda esta versatilidade característica do jogo o possibilita agir como um intermédio entre o aluno e o aprender, pois ele pode gerar diversos saberes e abranger várias áreas de conhecimento, sejam elas distintas ou não.

\subsection{Transdisciplinaridade}

A prática transdisciplinar na educação se dá na união de duas ou mais disciplinas, gerando a confrontação com vistas a criar novas realidades e, a partir daí, cria uma terceira área de conhecimento. No referido trabalho o jogo teatral é pensado como uma rede, cuja trama e pontos de conexão articulam os mais variados temas, e possibilitando ao jogador e ao espectador formar novos conceitos.

\subsection{Sustentabilidade}


O desenvolvimento sustentável visa conciliar o desenvolvimento econômico, a prevenção ambiental e o fim da pobreza no mundo, sendo este um caminho trilhado diariamente, com respeito mútuo e consciência de que todas as comunidades, pessoas e demais seres, são partes integrantes de um único ecossistema.

\section{Metodologia}

A metodologia geral que conduz a pesquisa é o método cartográfico estabelecido por Gilles Deleuze e Félix Guattari. O que eles pretendiam com o método era buscar um olhar diferente para o objeto pesquisado.

$\mathrm{Na}$ cartografia não há tópicos pré-estabelecidos pelo pesquisador, o pesquisador/cartógrafo se torna ator e autor da pesquisa, visto que ele não apenas a aplicará mas também experimentará o universo a ser pesquisado, pois os tópicos e as metas surgirão apenas durante processo.

\section{3- CONCLUSÃO}

O objetivo é levar o leitor a refletir sobre o jogo teatral como metodologia de ensino que possa articular saberes e conhecimentos distintos levando a confrontação de saberes, tendo em vista a suposição de uma metodologia de aprendizado que tenha como base o conceito transdisciplinar e o jogo teatral.

Vejo no trabalho transdisciplinar "a raiz" do pensamento sustentável, que para se desenvolver de maneira sustentável é necessário atuar de forma que esses três pilares (social, econômico e ambiental) coexistam e interajam entre si de forma plenamente harmoniosa, sendo que a transdisciplinaridade pode vir a possibilitar o indivíduo entender melhor os seus direitos e deveres de cidadão.

\section{4- REFERÊNCIAS}

D'AMBROSIO, Ubiratam. Transdisciplinaridade. São Paulo: Palas Athena, 1997.

HUIZINGA, Johan. Homo Ludens: o jogo como elemento da cultura. São Paulo: Perspectiva, 2008.

MORAES. Rodrigues. Danielle. O teatro na escola da lei à lida. 2011. Mestrado em Educação. Universidade Federal de São João del-Rei, 2011.

SANTOS, Akiko. Complexidade e transdisciplinaridade em educação: cinco princípios para resgatar o elo perdido. Revista Brasileira de Educação v. 13 n. 37 jan./abr. 2008 SIQUEIRA, Adilson. Arte e Sustentabilidade Argumentos para a pesquisa ecopoética da cena. MORINGA-Artes do Espetáculo, Volume 1, Edição, 2010 